\title{
Kualitas Layanan dan Kepuasan Pelanggan: Studi Eksplorasi atas Atribut Kualitas Layanan pada Fakultas Ekonomi Universitas Wijaya Kusuma Surabaya
}

\section{Kristiningsih \\ Adrianto Trimarjono}

Manajemen, Universitas Wijaya Kusuma Surabaya, Indonesia

Korespondensi penulis: kristiningsihamir017@gmail.com

\begin{abstract}
The purpose of this study was developing a service quality model in the business of higher education services at the Faculty of Economics, University of Wijaya Kusuma Surabaya, Indonesia which is grounded that can be used as the foundation of researchers in a service research and implementation for business practitioners of higher education services. This research used a qualitative research design with a critical incident technique model, which explored the answers of the student respondents and alumni service users to examine deeper the experience of understanding the most satisfying and the most unsatisfaction of institutions.
\end{abstract}

Keywords: Customer satisfaction, customer unsatisfaction, critical incident technique.

Abstrak: Tujuan dari penelitian ini adalah mengembangkan model kualitas layanan dalam bisnis pendidikan tinggi di Fakultas Ekonomi, Universitas Wijaya Kusuma Surabaya, Indonesia yang dimaksudkan sebagai landasan bagi para peneliti untuk mengembangkan penelitian dan implementasi bagi para praktisi bisnis layanan pendidikan tinggi. Penelitian ini menggunakan disain penelitian kualitatif dengan model teknik insiden kritis yang mengeksplorasi jawaban responden mahasiswa dan pengguna alumni untuk memeriksa lebih mendalam pengalaman mereka untuk memahami layanan institusi yang paling memuaskan dan paling tidak memuaskan.

Kata kunci: Kepuasan pelanggan, ketidakpuasan pelanggan, teknik insiden kritis.

Article Info:

Received: December 10, $2018 \quad$ Accepted: April 7, $2019 \quad$ Available Online: April 14, 2019

DOI: http://dx.doi.org/10.30588/jmp.v8i2.395

\section{LATAR BELAKANG}

Pada era globalisasi ini, perkembangan dunia bisnis mengalami kemajuan yang sangat pesat, baik perusahaan yang bergerak di bidang industri maupun jasa. Dampak dari perkembangan ini adalah banyaknya perusahaan yang tumbuh, berkembang, dan 
sukses.. Era globalisasi sangat menjanjikan adanya peluang maupun tantangan bisnis bagi perusahaan yang beroperasi di Indonesia. Industri jasa pendidikan, khususnya pendidikan tinggi, juga harus memikirkan bagaimana bisa bertumbuh dan berkembang dalam era persaingan yang semakin ketat. Lembaga pendidikan tinggi dituntut memiliki kemampuan menghasilkan lulusan yang berkualitas. Idealisme menciptakan kualitas pendidikan yang baik dan menjadi penyedia jasa berkualitas memerlukan perbaikan kualitas layanan yang harus seimbang. Oleh karena itu, perguruan tinggi harus mampu menyeimbangkan kedua tujuan tersebut.

Kualitas layanan sebuah perguruan tinggi lebih kompleks dalam pengukurannya. Pada banyak penelitian, pengukuran atas kualitas layanan diukur dari tingkat kepuasan penggunanya, baik mahasiswa sebagai pengguna layanan kampus, maupun perusahaan/ institusi luar sebagai pengguna lulusan yang mempercayakan para lulusan perguruan tinggi sebagai karyawannya. Pada beberapa penelitian, pengukuran perusahaan sebagai pengguna lulusan yang memperkerjakannya sebagai karyawan dalam bekerja kurang dieksplorasi pada penelitian sebelumnya. Dalam hal ini, kepuasan pelanggan adalah kepuasan mahasiswa dan masyarakat pengguna lulusan yang merupakan atribut penting dalam pemasaran, khususnya usaha jasa pendidikan tinggi. Usaha jasa dapat bersaing baik dengan pesaingnya bila dapat menciptakan kepuasan pelanggan atas kualitas layanan yang diberikannya.

Penelitian kualitas layanan pada usaha bidang jasa telah banyak dilakukan oleh peneliti di bidang pemasaran menggunakan skala pengukuran SERVQUAL (Service Quality) (Parasuraman \& Berry, 1988). Penelitian ini menawarkan pendekatan yang berbeda dengan menggunakan pendekatan pengukuran alternatif yang relatif masih terbatas. Sementara, layanan pada sektor jasa sangat beragam, baik dari aspek jenis layanan maupun jenis pelanggan yang menggunakan layanan tersebut. Penelitian ini menggunakan pendekatan kualitatif dengan metode Critical Incident Teqniques (CIT) untuk melakukan eksplorasi penyebab kepuasan maupun ketidakpuasan pelanggan. Penelitian ini bertujuan mengeksplorasi atribut-atribut kualitas layanan yang dapat menimbulkan kepuasan maupun ketidakpuasan bagi pelanggan institusi pendidikan tinggi Fakultas Ekonomi Universitas Wijaya Kusuma Surabaya (UWKS).

\section{KAJIAN TEORITIS}

\section{Pengertian dan Atribut Kepuasan Konsumen (Consumer Satisfaction)}

Dalam situasi persaingan yang semakin ketat, banyak produsen yang terlibat dalam pemenuhan kebutuhan dan keinginan konsumen. Banyak perusahaan yang menyertakan komitmennya terhadap kepuasan pelanggan dalam pernyataan misinya. Menurut Tjiptono (1997:24), kunci utama untuk memenangkan persaingan adalah memberikan nilai dan kepuasan kepada pelanggan melalui penyampaian produk atau jasa berkualitas dengan harga bersaing. Wilkie (1990, dalam Tjiptono, 1997:24) mendefinisikan kepuasan konsumen sebagai suatu tanggapan emosional pada evaluasi terhadap pengalaman konsumsi suatu produk atau jasa, sedangkan menurut Kotler et al. (1996, dalam Tjiptono 1997:24) mengatakan bahwa kepuasan pelanggan adalah tingkat perasaan seseorang setelah membandingkan kinerja (atau hasil) yang ia rasakan dibandingkan dengan harapannya. 
Selanjutnya, Dutka (1994) dalam Gabut (2010) menyusun tiga atribut pokok untuk mengukur kepuasan pelanggan, yaitu:

1. Attributes related to the poduct, produk merupakan apa saja, baik yang berwujud maupun tidak berwujud yang di dalamnya sudah termasuk warna, kemasan, pengecer, dan layanan yang diberikan dan dapat ditawarkan ke pasar untuk digunakan atau dikonsumsi, sehingga dapat memuaskan keinginan dan kebutuhannya. Atribut yang berkaitan dengan produk meliputi:

a) Product design merupakan proses untuk mendisain dan fungsi produk yang menarik.

b) Product features merupakan suatu ciri atau karakteristik tertentu yang dimiliki oleh suatu produk, sehingga berbeda dengan produk yang ditawarkan pesaing.

c) Product reliability merupakan keakuratan dan keandalan produk yang dihasilkan oleh suatu perusahaan dalam jangka waktu tertentu.

d) Product benefit merupakan manfaat yang diperoleh pelanggan dalam menggunakan produk yang dihasilkan oleh suatu perusahaan yang dijadikan dasar positioning untuk membedakan perusahaan tersebut dengan perusahaan lain.

e) Product quality merupakan penilaian mutu suatu produk.

f) Value price relationship merupakan faktor sentral dalam menentukan kepuasan konsumen. Apabila nilai yang diperoleh konsumen melebihi apa yang ia bayarkan, maka hal itu menjadi dasar penting penciptaan kepuasan konsumen.

g) Range of product or service merupakan macam produk/jasa layanan yang ditawarkan oleh suatu perusahaan.

2. Attributes related to service, atribut ini merupakan atribut pemuasan pelanggan yang berkaitan dengan pemberian pelayanan dan pasca pembelian. Atribut pelayanan meliputi:

a) Guarantee or warranty, merupakan jaminan yang diberikan oleh suatu perusahaan terhadap produk yang dapat dikembalikan bila kinerja produk tersebut tidak memuaskan.

b) Delivery, merupakan kecepatan dan ketepatan dari proses pengiriman produk dan jasa yang diberikan perusahaan terhadap konsumennya.

c) Complant handling, merupakan penanganan terhadap keluhan yang dilakukan oleh konsumen terhadap perusahaan.

d) Resolution of problem, merupakan kemampuan perusahaan dengan serius dan memecahkan masalah yang dihadapi oleh konsumen.

3. Attributes related to purchase, atribut pembelian merupakan atribut pemuasan pelanggan yang berkaitan dengan pemberian layanan pada saat pra pembelian dan pada saat pembelian. Atribut pembelian meliputi:

a) Courtesy merupakan kesopanan, perhatian, pertimbangan, dan keramahan yang dilakukan karyawan dalam melayani konsumennya.

b) Communication merupakan proses penyampaian informasi yang dilakukan oleh karyawan perusahaan kepada konsumennya. 
c) Ease or convenience acquisition merupakan kemudahan untuk mendapatkan pengetahuan tentang produk dari suatu perusahaan.

d) Company competence adalah kemampuan suatu perusahaan untuk mewujudkan permintaan yang diajukan oleh konsumen dalam memberikan layanan.

e) Company reputation adalah reputasi perusahaan yang dapat mempengaruhi pandangan konsumen terhadap perusahaan tersebut dan dapat mengurangi ketidakpastian dan risiko dalam keputusan pembelian.

\section{Kepuasan Mahasiswa terhadap Kualitas Layanan atau Pembelajaran}

Kepuasan merupakan persepsi seseorang terhadap sesuatu yang telah memenuhi harapannya. Kepuasan mahasiswa terhadap pembelajaran dapat dilihat dari lima dimensi kepuasan, yaitu: tangible, reliability, responsiveness, assurance, dan empathy. Dimensi pertama kualitas layanan adalah tangible. Tangible merupakan dimensi fisik. Suatu jasa tidak dapat dicium tetapi tidak dapat diraba, sehingga bukti fisik menjadi penting sebagai ukuran terhadap layanan. Tangible merupakan kemampuan menyediakan fasilitas fisik kampus dan perlengkapan perkuliahan yang memadai menyangkut penampilan dosen, serta sarana umum. Misalnya, ketersediaan sarana dan prasarana. Mahasiswa akan menilai suatu kualitas pembelajaran dari segala sarana dan fasilitas yang ada.

Dimensi kepuasan kedua adalah reliability, yaitu dimensi yang mengukur keandalan pendidikan tinggi dalam memberikan layanan kepada mahasiswanya. Ada dua aspek dimensi ini, yaitu: (1) kemampuan dosen untuk memberikan metode pembelajaran seperti yang dijanjikan, dan (2) seberapa jauh dosen memberikan pembelajaran secara akurat. Reliability merupakan kemampuan dosen dalam memberikan pembelajaran sesuai dengan yang dijanjikan, yaitu tepat waktu, segera, relevan, dan akurat, sehingga memuaskan mahasiswa.

Dimensi ketiga adalah responsiveness, yaitu dimensi kualitas layanan yang dinamis. Responsiveness merupakan kesediaan dan daya tanggap para dosen untuk membantu dan memberikan pembelajaran sesuai kebutuhan mahasiswa. Dimensi ini tampak pada situasi ketika dosen mudah ditemui untuk keperluan konsultasi akademik. Harapan mahasiswa terhadap keakuratan layanan akan selalu berubah dari waktu kewaktu.

Dimensi keempat kualitas layanan adalah assurance, yaitu dimensi jaminan kualitas yang berhubungan dengan perilaku staf pengajar atau dosen dalam menanamkan rasa percaya dan keyakinan kepada para mahasiswa. Assurance mencakup kompetensi, pengetahuan, ketrampilan, dan kesopanan. Contoh dimensi ini adalah sikap dosen ketika menyampaikan kuliah sesuai dengan bidang keahlian masing-masing. Dosen berusaha menambah wawasan dengan membaca, menghadiri seminar, mengikuti pelatihan, atau melakukan penelitian. Ada empat aspek dimensi assurance, yaitu keramahan, kornpetensi, kredibilitas, dan keamanan.

Dimensi kelima adalah empathy, yaitu sikap dosen dalam memberikan layanan dengan sepenuh hati, seperti perhatian secara pribadi dan pemahaman bahwa setiap mahasiswa memiliki kemampuan dan kebutuhan yang berbeda-beda. Sikap ini dapat ditunjukkan dengan pemahaman peran dosen yang tidak hanya sebagai pendidik melainkan juga sebagai konselor dan supervisor. Dimensi ini berkaitan dengan teori perkembangan kebutuhan manusia Maslow. Kebutuhan manusia tidak hanya berupa 
kebutuhan fisik, keamanan, dan social, tetapi juga kebutuhan ego dan aktualisasi diri. Dua kebutuhan terakhir tersebut banyak berhubungan dengan dimensi empati. Kepuasan mahasiswa dan kualitas layanan dalam proses pembelajaran memiliki keterkaitan yang kuat. Semakin berkualitas layanannya, maka semakin tinggi pula pencapaian kepuasan mahasiswa. Kepuasan mahasiswa merupakan esensi dalam pendekatan TQM (Total Quality Management). Oleh sebab itu, sebuah Perguruan Tinggi harus mampu mengidentifikasi kebutuhan para mahasiswa secara cermat dan berusaha memuaskannya dengan memandang bahwa mahasiswa adalah pelanggan utama yang harus dilayani (Margono, 2005).

\section{Kepuasan Pengguna Lulusan sebagai Konsumen Pendidikan}

Sistem pendidikan dapat dilihat sebagai sebuah sistem transformasi dengan input, proses, dan output (Sahney et al., 2004). Dunia pendidikan memiliki berbagai pengertian mengenai kualitas. Kualitas tersebut meliputi kualitas input, yaitu pelajar, staf pendukung, dan infrastruktur, kualitas proses yaitu proses pembelajaran dan aktivitas belajar mengajar, dan kualitas output yakni alumni yang kompeten dan cemerlang masa depannya (Sahney et al., 2004). Pengguna lulusan adalah pihak eksternal yang menjadi konsumen bagi output sebuah institusi pendidikan tinggi. Pihakpihak eksternal ini bisa berupa institusi pemerintah, swasta, maupun perorangan. Pengguna lulusan, baik perorangan maupun institusi akan menilai kinerja lulusan universitas yang menjadi karyawannya.

Pengertian kinerja adalah hasil dari prestasi kerja yang telah dicapai seorang karyawan sesuai dengan fungsi dan tugasnya pada periode tertentu (Bernadin \& Russell, 1993), sedangkan Maier (dikutip dari Peni, 2005) berpendapat bahwa kinerja karyawan merupakan keberhasilan seseorang dalam melaksanakan suatu pekerjaan. Penilaian terhadap kinerja karyawan diperlukan bukan hanya untuk mengevaluasi pekerjaan karyawannya, tetapi juga untuk mengembangkan dan memotivasi karyawan ke depannya (Simamora, 2001).

Handoko (1994) juga menekankan penilaian prestasi sebagai proses di dalam organisasi untuk mengevaluasi atau menilai prestasi kerja karyawan dengan tujuan untuk memperbaiki keputusan-keputusan personalia dan memberikan umpan balik kepada karyawan tentang pelaksanaan kerja mereka. Penilaian kinerja variabel kualitas lulusan menurut pengembangan softskills di perguruan tinggi (Sailah, 2008) yang terdiri atas tujuh elemen, yaitu: (1) Integritas (etika dan moral), (2) Keahlian berdasarkan bidang keilmuan (profesionalisme), (3) Bahasa Inggris, (4) Penguasaan teknologi informasi, (5) Komunikasi, (6) Kerjasama tim, dan (7) Pengembangan diri. Menurut Spencer et al. (1993), karyawan yang diharapkan oleh dunia kerja seharusnya memiliki beberapa kemampuan, yaitu: (1) Komitmen pada organisasi, (2) Keinginan berprestasi, (3) Melayani, (4) Kerjasama, (5) Proaktif, dan (6) Memimpin.

\section{METODE PENELITIAN}

\section{Pendekatan Penelitian}

Penelitian ini menggunakan pendekatan penelitian dengan paradigma kualitatif, karena mengamati gejala sosial yang terjadi di masyarakat. Disain penelitian ini menggunakan metode CIT (Critical Incident Technique). CIT merupakan metode eksploratif untuk menemukan variabel yang signifikan secara teoritis berdasarkan pendekatan 
induktif dari kejadian-kejadian dan episode kritis yang dialami responden. CIT menggunakan content analysis secara kualitatif terhadap jawaban diskriptif responden atas pertanyaan terbuka yang diajukan. CIT sangat berguna untuk menemukan variabel yang tidak diketahui dan tidak diantisipasi.

\section{Informan dalam penelitian}

Informan dalam penelitian ini adalah:

1. Final customer (pengguna lulusan), yaitu perusahaan yang memperkerjakan alumni Fakultas Ekonomi Universitas Wijaya Kusuma Surabaya.

2. Intermediary customer (mahasiswa), yaitu mahasiswa Fakultas Ekonomi Universitas Wijaya Kusuma Surabaya yang saat ini ada di semester empat atau sebelumnya.

Pemilihan informan intermediary customer mahasiswa di UWKS pada semester empat atau sebelumnya dilandasi oleh alasan bahwa mereka mengetahui lebih banyak tentang kualitas layanan di Fakultas Ekonomi UWKS, sedangkan untuk pengguna lulusan yaitu perusahaan yang mempekerjakan alumni Fakultas Ekonomi UWKS dipilih berdasarkan data pada Pusat Karir UWKS tentang daftar perusahaan yang mempekerjakan lulusan Fakultas Ekonomi UWKS.

\section{Teknik Analisis}

Penelitian ini menggunakan teknik analisis data kualitatif menggunakan metode Critical Incident Technique (Rhe \& Rha, 2008) yang meliputi langkah sebagai berikut:

1. Analisis data menggunakan CIT adalah klasifikasi dan konseptualisasi proses induktif. Setelah membaca semua insiden yang telah didiskripsikan, peneliti mengelompokkan orang-orang yang sama ke dalam berbagai kategori.

2. Proses membaca dan kategorisasi insiden diulang berkali-kali.

3. Kategorisasi dimodifikasi, dibagi, dan digabungkan, sehingga pola konseptual terpercaya akan muncul dari data.

4. Masing-masing kategori dalam hal kualitas layanan diberikan nama.

5. Selanjutnya dilakukan konsultasi dengan dua ahli dalam disiplin manajemen untuk mengembangkan skema klasifikasi insiden yang independen satu sama lain dan kemudian membandingkan klassifikasinya.

6. Skema dan perbedaan pendapat diselesaikan melalui diskusi. Melalui proses diskusi ini, secara bertahap disusun skema klasifikasi akhir.

7. Semua insiden diurutkan ke dalam berbagai kategori skema.

8. Selanjutnya, dua ahli akan membandingkan hasil mereka dan menghitung angka keandalan skor.

9. Apabila ada yang tidak setuju, hasil tersebut akan didiskusikan lebih lanjut untuk dibuat tabel frekuensi akhir dari kualitas layanan.

\section{HASIL DAN PEMBAHASAN}

\section{Kategorisasi Data Hasil Penelitian}


Dalam analisis data dengan menggunakan disain CIT, langkah pertama yang dilakukan adalah membaca narasi hasil uraian jawaban dari responden secara berulangulang. Selanjutnya, kategorisasi jawaban responden dilakukan berdasarkan kesamaan jawaban antarresponden. Hasil kategorisasi jawaban responden dirangkum dalam Tabel 1 berikut ini. Berdasarkan Tabel 1 tersebut, frekuensi terbanyak responden mahasiswa merasakan ketidakpuasan adalah ketersediaan fasilitas AC yang sering mati atau kurang dingin. Di dalam kelas, mahasiswa sering mendapati udara terasa panas yang disebabkan AC tidak berfungsi secara maksimal, sehingga hal ini akan mengganggu proses belajar mengajar.

Tabel 1. Kategorisasi Hasil Jawaban Informan Mahasiswa FE UWKS

\begin{tabular}{|c|c|c|c|}
\hline Kategori & Definisi & $\begin{array}{l}\text { Jumlah responden } \\
\text { Puas }\end{array}$ & $\begin{array}{c}\text { Jumlah } \\
\text { responden tidak } \\
\text { puas }\end{array}$ \\
\hline \multirow{14}{*}{$\begin{array}{l}\text { Layanan } \\
\text { Administratif }\end{array}$} & Antrian loket bank ramai. & & 5 \\
\hline & $\begin{array}{l}\text { Loket Bank Jatim kurang memadai } \\
\text { jumlahnya. }\end{array}$ & & 3 \\
\hline & $\begin{array}{l}\text { Jumlah tenaga administratif kurang } \\
\text { sesuai dengan jumlah mahasiswa. }\end{array}$ & & 2 \\
\hline & Susah meminta data administrasi. & & 1 \\
\hline & $\begin{array}{l}\text { Layanan hari terakhir biaya kuliah } \\
\text { selalu penuh. }\end{array}$ & & 2 \\
\hline & $\begin{array}{l}\text { Layanan BAA (Biro Administrassi } \\
\text { Akademik) lambat. }\end{array}$ & & 1 \\
\hline & $\begin{array}{l}\text { Mahasiswa mendapat solusi ketika } \\
\text { ada masalah administrtaif. }\end{array}$ & 3 & \\
\hline & $\begin{array}{l}\text { Petugas TU (Tata Usaha) yang } \\
\text { ramah. }\end{array}$ & 3 & \\
\hline & $\begin{array}{l}\text { Petugas TU yang acuh (kurang } \\
\text { senyum). }\end{array}$ & & 3 \\
\hline & $\begin{array}{l}\text { Layanan perpustakaan malam hari } \\
\text { tidak ada. }\end{array}$ & & 1 \\
\hline & $\begin{array}{l}\text { Layanan administratif malam hari } \\
\text { kurang. }\end{array}$ & & 3 \\
\hline & $\begin{array}{l}\text { Layanan administratif semester } \\
\text { pendek membingungkan. }\end{array}$ & & 1 \\
\hline & $\begin{array}{l}\text { Staf TU membantu saat mahasiswa } \\
\text { kesulitan melakukan KRS (Kartu } \\
\text { Rencana Studi) online. }\end{array}$ & 3 & \\
\hline & $\begin{array}{l}\text { Layanan plotting lab dan } \\
\text { pembayarannya berbelit-belit. }\end{array}$ & & 3 \\
\hline \multirow[t]{5}{*}{ Sistem informasi } & $\begin{array}{l}\text { Administrasi biaya kuliah kurang } \\
\text { teliti, terjadi kesalahan perhitungan } \\
\text { pembayaran biaya kuliah. }\end{array}$ & & 2 \\
\hline & $\begin{array}{l}\text { Informasi pengumuman tidak } \\
\text { disampaikan dengan jelas. }\end{array}$ & & 2 \\
\hline & Sistem pembayaran belum online. & & 4 \\
\hline & $\begin{array}{l}\text { Sistem informasi plotting lab } \\
\text { bersifat manual. }\end{array}$ & & 5 \\
\hline & $\begin{array}{l}\text { Sistem KHS (Kartu Hasil Studi) } \\
\text { online. }\end{array}$ & 6 & \\
\hline \multirow[t]{2}{*}{ Fasilitas } & $\begin{array}{l}\text { Air Conditioning (AC) kurang } \\
\text { dingin. }\end{array}$ & & 10 \\
\hline & Parkir kurang luas. & & 5 \\
\hline
\end{tabular}




\begin{tabular}{|c|c|c|c|}
\hline & \multicolumn{2}{|l|}{ Parkir berbayar. } & 11 \\
\hline & \multicolumn{2}{|l|}{$\begin{array}{l}\text { LCD/Proyektor tidak berfungsi } \\
\text { baik. }\end{array}$} & 7 \\
\hline & \multicolumn{2}{|l|}{ Kantin kurang luas. } & 2 \\
\hline & \multicolumn{2}{|l|}{ Tidak ada kursi di lobi. } & 3 \\
\hline & \multicolumn{2}{|l|}{ Perpustakaan kurang lengkap. } & 2 \\
\hline & \multicolumn{2}{|l|}{$\begin{array}{l}\text { Tidak ada tempat diskusi/ } \\
\text { mengerjakan tugas. }\end{array}$} & 4 \\
\hline & \multicolumn{2}{|l|}{ Wifi lambat. } & 1 \\
\hline & Fasilitas ruangan nyaman. & 4 & \\
\hline & \multicolumn{2}{|l|}{$\begin{array}{l}\text { Adanya pembatasan pemakaian } \\
\text { listrik. }\end{array}$} & 2 \\
\hline & \multicolumn{2}{|l|}{$\begin{array}{l}\text { Tidak ada tanda parkir mobil } \\
\text { penuh. }\end{array}$} & 1 \\
\hline & \multicolumn{2}{|l|}{$\begin{array}{l}\text { Tidak bisa keluar kamar mandi } \\
\text { karena kunci rusak. }\end{array}$} & 1 \\
\hline & Gedung bagus. & 1 & \\
\hline \multirow[t]{3}{*}{ Keamanan } & \multicolumn{2}{|l|}{ Fasilitas parkir kurang aman. } & 12 \\
\hline & \multicolumn{2}{|l|}{ Sering terjadi kehilangan helm. } & 2 \\
\hline & \multicolumn{2}{|l|}{ Pernah terjadi ban dikempeskan. } & 1 \\
\hline \multirow{14}{*}{$\begin{array}{l}\text { Kualitas } \\
\text { pengajaran }\end{array}$} & Kualitas dosen cukup baik. & 7 & \\
\hline & $\begin{array}{l}\text { Ada dosen yang kurang menguasai } \\
\text { materi kuliah. }\end{array}$ & & 2 \\
\hline & $\begin{array}{l}\text { Dosen pembimbing memberikan } \\
\text { solusi. }\end{array}$ & 1 & \\
\hline & Standar nilai baik. & 4 & \\
\hline & \multicolumn{2}{|l|}{$\begin{array}{l}\text { Ada dosen yang memberi standar } \\
\text { nilai yang terlalu ketat. }\end{array}$} & 1 \\
\hline & \multicolumn{2}{|l|}{$\begin{array}{l}\text { Dosen tidak fleksibel ketika ada } \\
\text { mahasiswa absen karena lembur } \\
\text { kerja. }\end{array}$} & 1 \\
\hline & \multicolumn{2}{|l|}{$\begin{array}{l}\text { Kurikulum baik sesuai standar } \\
\text { kebutuhan. }\end{array}$} & \\
\hline & \multicolumn{2}{|l|}{$\begin{array}{l}\text { Nilai pada KHS bagus karena } \\
\text { standar yang ditetapkan. }\end{array}$} & \\
\hline & \multicolumn{2}{|l|}{$\begin{array}{l}\text { Dosen berhalangan mengajar tidak } \\
\text { ada pemberitahuan sebelumnya. }\end{array}$} & 1 \\
\hline & \multicolumn{2}{|l|}{$\begin{array}{l}\text { Beberapa dosen sering terlambat } \\
\text { datang mengajar. }\end{array}$} & 3 \\
\hline & \multicolumn{2}{|l|}{$\begin{array}{l}\text { Sistem belajar mengajar agak } \\
\text { membosankan (kurang variatif). }\end{array}$} & 1 \\
\hline & \multicolumn{2}{|l|}{$\begin{array}{l}\text { Ada dosen yang bagus dalam } \\
\text { memberikan nilai. }\end{array}$} & \\
\hline & \multicolumn{2}{|l|}{$\begin{array}{l}\text { Ada juga dosen yang suka mencari } \\
\text { kesalahan mahasiswa. }\end{array}$} & 2 \\
\hline & Ada kuliah tamu. & 1 & \\
\hline \multirow[t]{2}{*}{ Biaya } & \multicolumn{2}{|l|}{ Biaya pendidikan makin mahal. } & 10 \\
\hline & \multicolumn{2}{|l|}{ Biaya parkir kendaraan. } & 12 \\
\hline \multirow[t]{4}{*}{ Interaksi sosial } & Banyak teman ketika kuliah. & 3 & \\
\hline & $\begin{array}{l}\text { Kedekatan dosen dengan } \\
\text { mahasiswa. }\end{array}$ & 6 & \\
\hline & $\begin{array}{l}\text { Keterbukaan dosen berkomunikasi } \\
\text { dengan telepon atau Whatsapp. }\end{array}$ & 1 & \\
\hline & $\begin{array}{l}\text { Banyak dosen yang baik, santai } \\
\text { dalam mengajar. }\end{array}$ & 2 & \\
\hline Kemahasiswaan & \multicolumn{2}{|l|}{ Tidak ada pentas seni yang dapat } & 1 \\
\hline
\end{tabular}




\begin{tabular}{lll}
\hline menyalurkan bakat mahasiswa. & \\
\cline { 2 - 3 } $\begin{array}{l}\text { Tidak ada kegiatan mahasiswa } \\
\text { untuk mencari bakat. }\end{array}$ & 1 \\
& $\begin{array}{l}\text { Pemberian sertifikat kegiatan } \\
\text { mahasiswa tidak maksimal. }\end{array}$ & 1 \\
\hline $\begin{array}{l}\text { Ada kegiatan bazar untuk } \\
\text { mahasiswa. }\end{array}$ & 2 & $\mathbf{1 3 7}$ \\
\hline \multicolumn{1}{c}{ JUMLAH } & $\mathbf{5 8}$ & \\
\hline Sumber: Hasil penelitian lapangan.
\end{tabular}

Sumber: Hasil penelitian lapangan.

Permasalahan parkir bagi mahasiswa dianggap mahal dan sering terjadi kehilangan helm. Pada intinya, mahasiswa merasa keberatan dengan sistem parkir berbayar. Namun, hal ini tidak diimbangi dengan kualitas layanan yang memadai karena seringnya terjadi kehilangan helm tanpa adanya tanggung jawab dari pihak keamanan parkir. Suatu ketika, ada mahasiswa yang mendapati ban motornya kempes dan petugas parkir tidak mengetahuinya. Pada beberapa universitas lain, parkir motor tidak berbayar, sehingga hal tersebut membuat mahasiswa FE UWKS merasa tidak puas dengan layanan parkir. Selain itu, lahan parkir mobil dirasa kurang luas.

Hal lain yang membuat mahasiswa FE UWKS tidak puas adalah masalah antrian saat pembayaran biaya kuliah. Antrian dirasakan ramai dan jumlah loket tidak sesuai dengan jumlah mahasiswa ketika pembayaran biaya kuliah memasuki hari terakhir. Kesalahan perhitungan pembayaran biaya kuliah terjadi beberapa kali dan petugas tidak mengetahuinya. Hal lain yang membuat mahasiswa tidak puas adalah mereka menilai fasilitas yang diberikan masih kurang, seperti layanan perpustakaan yang kurang maksimal, tidak adanya tempat duduk di lobi, pembatasan listrik, LCD/proyektor yang terkadang macet, maupun ploting laboratorium yang masih dilakukan secara manual. Mahasiswa juga mengeluhkan biaya pendidikan semakin mahal. Sebaliknya, responden mahasiswa merasakan pengalaman yang sangat memuaskan pada beberapa hal, yaitu kurikulum yang sudah bagus, standar nilai yang baik, gedung yang bagus, serta sistem KHS dan KRS online yang memudahkan mahasiswa dalam proses heregistrasi.

Mahasiswa merasakan kepuasan dari interaksi dosen dengan mahasiswa yang dirasakan cukup baik. Dosen cukup terbuka dalam berkomunikasi melalui WA maupun telepon, sehingga mereka mudah berinteraksi. Namun, mereka juga mengeluhkan adanya dosen yang sering terlambat datang mengajar atau tidak masuk tanpa pemberitahuan sebelumnya. Tata usaha pun cukup membantu ketika mahasiswa mengalami kesulitan melakukan administrasi. Selain itu, mahasiswa merasa puas atas hubungan pertemanan dengan mahasiswa lain, penyelenggaraan bazar untuk acara-acara tertentu, dan mereka mengharapkan lebih banyak acara-acara pentas seni.

Berdasarkan Tabel 2 berikut ini, pengguna alumni merasakan ketidakpuasan atas kinerja alumni FE UWKS yang berkaitan dengan kemampuan berkomunikasi, khususnya dalam berbahasa Inggris, penguasaan teknologi informasi, dan kurang tepat waktu, seperti terlambat hadir atau terlambat dalam mengerjakan target sesuai waktu yang dibebankan. Sebagian pengguna alumni FE UWKS menganggap alumni yang berkerja pada mereka kurang kreatif, kurang menyukai tantangan baru, dan cenderung tidak suka berpendapat. Namun, pengguna alumni FE UWKS merasa puas atas kinerja alumni yang patuh pada aturan, ramah, sopan santun, mampu bekerjasama dengan karyawan lain, mampu bekerja dalam tekanan, memiliki target dalam pekerjaan, menyukai kegi- 
atan pelatihan, mandiri dalam menjalankan pekerjaannya, memiliki semangat untuk bekerja keras, mampu berkomunikasi secara baik dengan atasan, bekerja sesuai standar, dan bekerja sesuai SOP yang berlaku.

Tabel 2. Kategorisasi Jawaban Informan Pengguna Alumni FE UWKS

\begin{tabular}{|c|c|c|c|}
\hline Kategori & Definisi & $\begin{array}{l}\text { Jumlah } \\
\text { responden } \\
\text { puas } \\
\end{array}$ & $\begin{array}{c}\text { Jumlah } \\
\text { responden tidak } \\
\text { puas } \\
\end{array}$ \\
\hline \multirow[t]{4}{*}{ Komunikasi } & $\begin{array}{l}\text { Mau menerima masukan orang } \\
\text { lain. }\end{array}$ & 2 & \\
\hline & $\begin{array}{l}\text { Kurang dalam kemampuan } \\
\text { komunikasi berbahasa asing } \\
\text { (Bahasa Inggris). }\end{array}$ & & 4 \\
\hline & $\begin{array}{l}\text { Mampu menggunakan bahasa tulis } \\
\text { (membuat laporan). }\end{array}$ & 2 & \\
\hline & $\begin{array}{l}\text { Mampu berkomunikasi baik } \\
\text { dengan atasan. }\end{array}$ & 2 & \\
\hline \multirow[t]{5}{*}{ Organizational skill } & $\begin{array}{l}\text { Mampu menjalankan SOP } \\
\text { (Standard Operating Procedure) } \\
\text { pekerjaan. }\end{array}$ & 2 & \\
\hline & Kurang tepat waktu. & & 3 \\
\hline & Kinerja sudah sesuai standar. & 2 & \\
\hline & $\begin{array}{l}\text { Mampu memenuhi target jumlah } \\
\text { pekerjaan. }\end{array}$ & 2 & \\
\hline & Bekerja keras dan semangat. & 2 & \\
\hline \multirow[t]{2}{*}{ Leadership } & Mampu mengarahkan anak buah. & 1 & \\
\hline & Mampu mengkoordinasi kegiatan. & 1 & \\
\hline \multirow[t]{2}{*}{ Logic } & Mandiri dalam bekerja. & 2 & \\
\hline & Kreatifitas masih perlu perbaikan. & & 2 \\
\hline \multirow[t]{5}{*}{ Effort } & Mampu bekerja dalam stress tinggi. & 1 & \\
\hline & $\begin{array}{l}\text { Tidak terlalu menyukai tantangan } \\
\text { baru. }\end{array}$ & & 1 \\
\hline & Menyukai kegiatan training. & 2 & \\
\hline & $\begin{array}{l}\text { Mempunyai target yang tinggi } \\
\text { dalam bekerja. }\end{array}$ & 2 & \\
\hline & Tidak suka berpendapat. & & 2 \\
\hline \multirow[t]{2}{*}{ Group-skill } & $\begin{array}{l}\text { Kurang percaya diri pada } \\
\text { lingkungan baru. }\end{array}$ & & 3 \\
\hline & $\begin{array}{l}\text { Mampu bekerjasama dengan } \\
\text { karyawan lain. }\end{array}$ & 2 & \\
\hline \multirow[t]{4}{*}{ Etika } & Ramah. & & \\
\hline & Sopan santun. & 2 & \\
\hline & Pendiam. & & 1 \\
\hline & Patuh pada aturan yang berlaku. & 3 & \\
\hline Lain-lain & $\begin{array}{l}\text { Penguasaan teknologi informasi } \\
\text { sedang. }\end{array}$ & & 3 \\
\hline & JUMLAH & 30 & 19 \\
\hline
\end{tabular}

Sumber: Hasil penelitian lapangan.

\section{Triangulasi Data}

Selanjutnya, konsultasi dengan dua ahli dalam disiplin manajemen dilakukan untuk mengembangkan skema klasifikasi insiden independen satu sama lain dan 
membandingkan klasifikasi mereka untuk proses triangulasi. Dengan demikian, konsultasi dengan dua ahli manajemen dilakukan untuk mengetahui proses pengajaran dan layanan di Fakultas Ekonomi Universitas Wijaya Kusuma Surabaya. Konsultasi ahli dilakukan dengan:

1. Ketua Pusat Karir UWKS yang telah memiliki data hasil tracer study alumni dan pengguna alumni untuk mengkonfirmasi tentang data yang diperoleh dari pengguna alumni FE UWKS.

2. Wakil Dekan Bidang Akademik FE UWKS untuk mengkonfirmasi data yang diperoleh dari mahasiswa FE UWKS.

\section{Skema Klasifikasi Akhir}

Skema dan perbedaan pendapat yang terjadi antara hasil jawaban responden dengan pendapat ahli manajemen yang dipilih diselesaikan melalui diskusi. Dalam proses ini, secara bertahap penyusunan skema klasifikasi akhir dilakukan. Skema klasifikasi akhir ini merupakan jawaban responden yang telah divalidasi kebenarannya dengan pendapat ahli manajemen yang ditunjuk. Hasil klasifikasi akhir ditunjukkan dalam Tabel 3 berikut ini.

Tabel 3. Skema Klasifikasi Akhir Kepuasan Mahasiswa FE UWKS

\begin{tabular}{|c|c|c|c|}
\hline Kategori & Definisi & Memuaskan & Tidak Memuaskan \\
\hline \multirow[t]{9}{*}{$\begin{array}{l}\text { Layanan } \\
\text { Administratif }\end{array}$} & $\begin{array}{l}\text { Tenaga administratif } \\
\text { jumlahnya kurang sesuai } \\
\text { dengan jumlah mahasiswa. }\end{array}$ & & (2) \\
\hline & $\begin{array}{l}\text { Susah meminta data } \\
\text { administrasi. }\end{array}$ & & $\sqrt{ }$ \\
\hline & $\begin{array}{l}\text { Mahasiswa mendapat solusi } \\
\text { ketika ada masalah } \\
\text { administrative. }\end{array}$ & $\sqrt{ }$ & \\
\hline & Petugas TU ramah. & $\sqrt{ }$ & \\
\hline & $\begin{array}{l}\text { Petugas TU acuh (kurang } \\
\text { senyum). }\end{array}$ & & $\sqrt{ }$ \\
\hline & $\begin{array}{l}\text { Layanan administratif malam } \\
\text { hari kurang. }\end{array}$ & & $\sqrt{ }$ \\
\hline & $\begin{array}{l}\text { Layanan administratif } \\
\text { semester pendek } \\
\text { membingungkan. }\end{array}$ & & $\sqrt{ }$ \\
\hline & $\begin{array}{l}\text { Staf TU membantu saat } \\
\text { mahasiswa kesulitan dalam } \\
\text { KRS online. }\end{array}$ & $\sqrt{ }$ & \\
\hline & $\begin{array}{l}\text { Layanan plotting lab dan } \\
\text { pembayarannya berbelit- } \\
\text { belit. }\end{array}$ & & $\sqrt{ }$ \\
\hline \multirow[t]{3}{*}{ Sistem informasi } & $\begin{array}{l}\text { Informasi pengumuman tidak } \\
\text { disampaikan dengan jelas. }\end{array}$ & & $\sqrt{ }$ \\
\hline & $\begin{array}{l}\text { Sistem informasi plotting lab } \\
\text { bersifat manual. }\end{array}$ & & $\sqrt{ }$ \\
\hline & Sistem KHS online. & $\sqrt{ }$ & \\
\hline \multirow[t]{2}{*}{ Fasilitas } & AC kurang dingin. & & $\sqrt{ }$ \\
\hline & LCD/Proyektor tidak & & $\sqrt{ }$ \\
\hline
\end{tabular}




\begin{tabular}{|c|c|c|c|}
\hline & \multicolumn{3}{|l|}{ berfungsi baik. } \\
\hline & \multicolumn{2}{|l|}{ Tidak ada kursi di lobi. } & $\sqrt{ }$ \\
\hline & \multicolumn{2}{|l|}{$\begin{array}{l}\text { Tidak ada tempat diskusi } \\
\text { untuk mengerjakan tugas. }\end{array}$} & $\sqrt{ }$ \\
\hline & Fasilitas ruangan nyaman. & $\sqrt{ }$ & \\
\hline & $\begin{array}{l}\text { Tidak bisa keluar kamar } \\
\text { mandi karena kunci rusak. }\end{array}$ & & $\sqrt{ }$ \\
\hline & Gedung bagus. & $\sqrt{ }$ & \\
\hline \multirow[t]{14}{*}{ Kualitas pengajaran } & Kualitas dosen cukup baik. & $\sqrt{ }$ & \\
\hline & \multicolumn{2}{|l|}{$\begin{array}{l}\text { Ada dosen yang kurang } \\
\text { menguasai materi kuliah. }\end{array}$} & $\sqrt{ }$ \\
\hline & $\begin{array}{l}\text { Dosen pembimbing memberi } \\
\text { solusi. }\end{array}$ & $\sqrt{ }$ & \\
\hline & Standar nilai baik. & $\sqrt{ }$ & \\
\hline & \multicolumn{2}{|l|}{$\begin{array}{l}\text { Ada dosen yang memberi } \\
\text { standar nilai yang terlalu } \\
\text { ketat. }\end{array}$} & $\sqrt{ }$ \\
\hline & \multicolumn{2}{|l|}{$\begin{array}{l}\text { Dosen tidak fleksible ketika } \\
\text { ada mahasiswa absen karena } \\
\text { lembur kerja. }\end{array}$} & $\sqrt{ }$ \\
\hline & $\begin{array}{l}\text { Kurikulum baik sesuai } \\
\text { standar kebutuhan. }\end{array}$ & $\sqrt{ }$ & \\
\hline & $\begin{array}{l}\text { Nilai pada KHS bagus } \\
\text { karena standar yang } \\
\text { ditetapkan. }\end{array}$ & $\sqrt{ }$ & \\
\hline & \multicolumn{2}{|l|}{$\begin{array}{l}\text { Dosen berhalangan mengajar } \\
\text { tidak ada pemberitahuan } \\
\text { sebelumnya. }\end{array}$} & $\sqrt{ }$ \\
\hline & \multicolumn{2}{|l|}{$\begin{array}{l}\text { Beberapa dosen sering } \\
\text { terlambat datang mengajar. }\end{array}$} & $\sqrt{ }$ \\
\hline & \multicolumn{2}{|l|}{$\begin{array}{l}\text { Sistem belajar mengajar agak } \\
\text { membosankan (kurang } \\
\text { variatif). }\end{array}$} & $\sqrt{ }$ \\
\hline & $\begin{array}{l}\text { Ada dosen yang bagus dalam } \\
\text { memberikan nilai. }\end{array}$ & $\sqrt{ }$ & \\
\hline & \multicolumn{2}{|l|}{$\begin{array}{l}\text { Ada juga dosen yang suka } \\
\text { mencari kesalahan } \\
\text { mahasiswa. }\end{array}$} & $\sqrt{ }$ \\
\hline & Ada kuliah tamu. & $\sqrt{ }$ & \\
\hline Biaya & \multicolumn{2}{|l|}{$\begin{array}{l}\text { Biaya pendidikan makin } \\
\text { mahal. }\end{array}$} & $\sqrt{ }$ \\
\hline \multirow[t]{4}{*}{ Interaksi sosial } & Banyak teman ketika kuliah. & $\sqrt{ }$ & \\
\hline & $\begin{array}{l}\text { Kedekatan dosen dengan } \\
\text { mahasiswa. }\end{array}$ & $\sqrt{ }$ & \\
\hline & $\begin{array}{l}\text { Keterbukaan dosen } \\
\text { berkomunikasi dengan BBM } \\
\text { atau WA. }\end{array}$ & $\sqrt{ }$ & \\
\hline & \multicolumn{2}{|l|}{$\begin{array}{l}\text { Banyak dosen yang baik, } \\
\text { santai dalam mengajar. }\end{array}$} & \\
\hline \multirow[t]{3}{*}{ Kemahasiswaan } & \multicolumn{2}{|l|}{$\begin{array}{l}\text { Tidak ada pentas seni yang } \\
\text { menyalurkan bakat } \\
\text { mahasiswa. }\end{array}$} & $\sqrt{ }$ \\
\hline & \multicolumn{2}{|l|}{$\begin{array}{l}\text { Tidak ada kegiatan } \\
\text { mahasiswa untuk mencari } \\
\text { bakat. }\end{array}$} & $\sqrt{ }$ \\
\hline & \multicolumn{2}{|l|}{$\begin{array}{l}\text { Pemberian sertifikat kegiatan } \\
\text { mahasiswa tidak maksimal. }\end{array}$} & $\sqrt{ }$ \\
\hline
\end{tabular}


Ada kegiatan bazar untuk mahasiswa.

Sumber: Hasil penelitian lapangan.

Hasil klasifikasi akhir untuk kepuasan mahasiswa terhadap layanan di Fakultas Ekonomi Universitas Wijaya Kusuma Surabaya menghasilkan tujuh kategori yang memuaskan dan tidak memuaskan, yaitu: layanan administratif, sistem informasi, fasilitas, kualitas pengajaran, biaya, interaksi social, dan kemahasiswaan.

Tabel 4. Skema klasifikasi Akhir Kepuasan Pengguna Alumni FE UWKS

\begin{tabular}{|c|c|c|c|}
\hline Kategori & Definisi & Memuaskan & Tidak Memuaskan \\
\hline \multirow[t]{3}{*}{ Komunikasi } & $\begin{array}{l}\text { Kurang dalam komunikasi } \\
\text { berbahasa asing (Inggris). }\end{array}$ & & $\sqrt{ }$ \\
\hline & $\begin{array}{l}\text { Mampu menggunakan } \\
\text { bahasa tulis (membuat } \\
\text { laporan). }\end{array}$ & $\sqrt{ }$ & \\
\hline & $\begin{array}{l}\text { Mampu berkomunikasi } \\
\text { secara baik dengan atasan. }\end{array}$ & $\sqrt{ }$ & \\
\hline \multirow[t]{4}{*}{$\begin{array}{l}\text { Organizational } \\
\text { skill }\end{array}$} & $\begin{array}{l}\text { Mampu menjalankan SOP } \\
\text { pekerjaan. }\end{array}$ & $\sqrt{ }$ & \\
\hline & Kurang tepat waktu. & & $\sqrt{ }$ \\
\hline & $\begin{array}{l}\text { Kinerja sudah sesuai } \\
\text { standar. }\end{array}$ & $\sqrt{ }$ & \\
\hline & $\begin{array}{l}\text { Mampu memenuhi target } \\
\text { jumlah pekerjaan. }\end{array}$ & $\sqrt{ }$ & \\
\hline \multirow[t]{2}{*}{ Leadership } & $\begin{array}{l}\text { Mampu mengarahkan anak } \\
\text { buah. }\end{array}$ & $\sqrt{ }$ & \\
\hline & $\begin{array}{l}\text { Mampu mengkoordinasi } \\
\text { kegiatan. }\end{array}$ & $\sqrt{ }$ & \\
\hline \multirow[t]{2}{*}{ Mindset } & Mandiri dalam bekerja. & $\sqrt{ }$ & \\
\hline & $\begin{array}{l}\text { Kreatifitas masih perlu } \\
\text { perbaikan. }\end{array}$ & & $\sqrt{ }$ \\
\hline \multirow[t]{4}{*}{ Effort } & $\begin{array}{l}\text { Tidak terlalu menyukai } \\
\text { tantangan baru. }\end{array}$ & & $\sqrt{ }$ \\
\hline & Menyukai kegiatan training. & $\sqrt{ }$ & \\
\hline & $\begin{array}{l}\text { Memiliki target yang tinggi } \\
\text { dalam bekerja. }\end{array}$ & $\sqrt{ }$ & \\
\hline & Tidak suka berpendapat. & & $\sqrt{ }$ \\
\hline \multirow[t]{2}{*}{ Group-skill } & $\begin{array}{l}\text { Kurang percaya diri pada } \\
\text { lingkungan baru. }\end{array}$ & & $\sqrt{ }$ \\
\hline & $\begin{array}{l}\text { Mampu bekerjasama } \\
\text { dengan karyawan lain. }\end{array}$ & $\sqrt{ }$ & \\
\hline \multirow[t]{4}{*}{ Etika } & Ramah . & $\sqrt{ }$ & \\
\hline & Sopan santun. & $\sqrt{ }$ & \\
\hline & Pendiam. & & $\sqrt{ }$ \\
\hline & $\begin{array}{l}\text { Patuh pada aturan yang } \\
\text { berlaku. }\end{array}$ & $\sqrt{ }$ & \\
\hline
\end{tabular}

Sumber: Hasil penelitian lapangan. 
Hasil skema klasifikasi akhir dari pengguna alumni FE UWKS tentang kepuasan dan ketidakpuasannya atas kinerja alumni menghasilkan tujuh kategori klasifikasi, yaitu komunikasi, organizational skill, leadership, mindset, effort, group-skill, dan etika.

\section{KESIMPULAN}

Dari hasil penelitian dan pembahasan yang dikemukakan di atas, maka penelitian ini menyimpulkan bahwa:

1. Hasil observasi menunjukkan bahwa mahasiswa FE UWKS memiliki insiden kritis lebih banyak pada faktor ketidakpuasan yang dialaminya daripada faktor kepuasan yang dialaminya atas layanan di Fakultas Ekonomi Universitas Wijaya Kusuma Surabaya.

2. Hasil observasi menunjukkan bahwa pengguna alumni FE UWKS memiliki insiden kritis lebih banyak pada faktor kepuasan yang dialaminya daripada faktor ketidakpuasan yang dialaminya atas kinerja para alumni Fakultas Ekonomi Universitas Wijaya Kusuma Surabaya yang bekerja pada instansinya.

3. Hasil klasifikasi akhir untuk kepuasan mahasiswa terhadap layanan di Fakultas Ekonomi Universitas Wijaya Kusuma Surabaya menghasilkan tujuh kategori yang memuaskan dan tidak memuaskan, yaitu: layanan administratif, sistem informasi, fasilitas, kualitas pengajaran, biaya, interaksi social, dan kemahasiswaan.

4. Hasil skema klasifikasi akhir dari pengguna alumni Fakultas Ekonomi Universitas Wijaya Kusuma Surabaya tentang kepuasan dan ketidakpuasannya atas kinerja alumni FE UWKS yang menghasilkan tujuh kategori klasifikasi, yaitu: komunikasi, organizational skill, leadership, mindset, effort, group-skill, dan etika.

\section{SARAN}

1. Bagi pimpinan Fakultas Ekonomi Universitas Wijaya Kusuma Surabaya, hasil penelitian ini dapat dijadikan wacana untuk perbaikan layanan pada mahasiswa, khususnya pada factor-faktor kritis yang menjadi sumber ketidakpuasan meliputi:

a. Perawatan pada fasilitas, seperti AC, LCD/proyektor, dan perbaikan pintu kamar mandi agar bisa berfungsi optimal.

b. Sarana parkir yang berbayar sebaiknya ditiadakan karena dirasa memberatkan, dan perlunya peningkatan keamanan area parkir.

c. Pengadaan kursi di lobi untuk tempat menunggu jeda sebelum kulaih maupun tempat diskusi mahasiswa.

d. Plotting laboratorium secara online.

e. Setiap pengumuman dapat disosialisaikan secara luas.

2. Terkait dengan ketidakpuasan pengguna alumni FE UWKS atas kinerja alumni yang bekerja di instransinya, maka perbaikan kurikulum pendidikan perlu dilkukan terkait kemampuan berbahasa Inggris, melatih kreatifitas, kedisiplinan, dan kemampuan dalam mengemukakan pendapat.

3. Untuk penelitian selanjutnya, faktor-faktor yang ditemukan sebagai kategori merupakan sumber kepuasan dan ketidakpuasan mahasiswa dan pengguna alumni yang dapat dibuktikan dalam suatu penelitian kuantitatif dan bersifat confirmatory 
research, sehingga penelitian mendatang akan menciptakan kesinambungan ilmiah yang mendukung penelitian ini.

\section{DAFTAR REFERENSI}

Bernadin, H. J. \& Russell, J. E. A. (1993). Human Resources Management. Singapore: MacGraw-Hill Book, Inc.

Gabut, D. N. (2010). Pengaruh Trust in A Brand dan Consumer Satisfaction terhadap Brand Loyalty pada Konsumen Teh Botol Sosro di Kota Depok. Jurnal Manajemen, Fakultas Ekonomi, Universitas Gunadarma.

Gremler, D. D. (2004). The Critical Incident Technique in Service Research. Journal of Service Research, 7(1): 65-89.

Handoko, T. H. (1994). Manajemen Personalia dan Sumber Daya Manusia. Yogyakarta: BPFE.

Kotler, P. \& Armstrong, G. (2001). Prinsip-Prinsip Pemasaran. Jilid 1. Edisi Kedelapan. Jakarta: Erlangga.

Kotler, P. \& Lane, K. K. (2008). Manajemen Pemasaran. Jakarta: PT Indeks.

Margono, G. (2005). Validitas Konstruk Instrumen Pengukur Tingkat Kepuasan Mahasiswa sebagai Pelanggan Internal. Jurnal PTM, 5(1), 9-18.

Parasuraman, A., Zeithaml, V. A., \& Berry, L. L. (1988). Servqual: A multiple-item scale for measuring consumer perc. Journal of Retailing, 64(1), 12.

Peni, K. (2005). Pengaruh Imbalan terhadap Kinerja Karyawan. Tesis Magister. Program Studi Teknik dan Manajemen Industri, Institut Teknologi Bandung.

Rhee, S-K. \& Rha, J-Y. (2009). Public Service Quality and Customer Satisfaction: Exploring the Attributes of Service Quality in the Public Sector. The Service Industries Journal, 29 (11): 1491-1512

Sahney, S., Banwet, D. K., \& Karunes, S. (2004). Conceptualizing total quality management in higher education. The TQM Magazine, 16(2), 145-159.

Sailah, I. (2008). Pengembangan Softskills di Perguruan Tinggi. Jakarta: Ditjend Dikti Depdiknas RI.

Simamora, H. (1997). Manajemen Sumber Daya Manusia. Edisi Kedua. Yogyakarta: BP Sekolah Tinggi Ilmu Ekonomi YKPN.

Spencer, M. L. \& Signe (1993). Competence at Work, Models for Superior Performance. New Jersey: John Wiley \& Sons, Inc.

Tjiptono, Fandy (1997). Strategi Pemasaran. Edisi II. Yogyakarta: Andi Offset. 